\title{
Jean Devanny, 1894-1962
}

\section{Carole Ferrier}

In 1980, Keri Hulme commented upon the 'intense sisterhood' that she felt with 'women like Jean Devanny.' She saw her as 'exploring things on the fringes that were very important to women way back then', and considered it 'very freeing (and very oppressive at the same time) to realise how completely these women were submerged' (101). To be on the fringes in the early years of the twentieth century could indeed be simultaneously oppressive and freeing, and this is illustrated in complex ways in Devanny's fiction, which negotiates issues of gender, race, ethnicity, sexuality and class, working with but also problematising the relationship between the material conditions of life and a variety of sometimes clashing ideologies. The specificities of the New Zealand and Australian contexts in which she lived and worked also produced particular effects. But, despite vicissitudes, Jean Devanny remained far from submerged and kept on waving - not drowning - as I demonstrated extensively when in 1999, after twenty years of research, I published her biography Jean Devanny: Romantic Revolutionary (hereafter RR).

Devanny was born Jane Crook in 1894, the eighth of ten children, at Ferntown a small sea-side settlement at the top of the South Island. She wrote in her autobiography (a version was posthumously published as Point of Departure, hereafter PD) that her maternal grandparents were from an upperclass background. This seems to have been a family legend, and the alleged colonel actually a sergeant, although it is true that he was involved in military operations in India and then the Maori Wars. The Crook family lived in the mining communities where her father, a boilermaker who had emigrated from England at around the age of 20, was employed. By the time Devanny left school at the age of 13 she had already changed her name from Jane to the Jean that her teacher preferred - it was this teacher along with her brothers who initially provided the books for the self-education she would pursue all her life. At the age of 17 , when the family had moved to Puponga, she married a miner, Hal Devanny, and he found work in several other mining settlements, including Fairfield near Dunedin, before they settled in Wellington at the beginning of the 1920s with their two children, a third having died in infancy. In 1929 the family emigrated to Australia. Devanny joined the Communist Party in Sydney in 1930, and was soon put in charge of building one of its front organisations, the Workers' International Relief. In this capacity she was sent for several months to Berlin and the Soviet Union in 1931. She separated from Hal soon after her return and throughout the 1930s had a close liaison 
with the leader of the Australian Communist Party, J.B. Miles. From the middle of that decade she spent increasing amounts of time in north Queensland whose sugar cane country and coral reefs became the setting of much of her later fiction and travel writing. In 1950, following a reconciliation with $\mathrm{Hal}$, she moved to Townsville in north Queensland, and lived there until her death in 1962.

Devanny's first attempt at extended writing was non-fictional theorising of gender and race. Her 'Evolution of the Sex Life' is a kind of precursor to Simone de Beauvoir's 1949 The Second Sex, and she also produced another manuscript called 'The Sexlife of the Maoris.' None of this sociological - or sexological - work aiming at a 'scientific' approach was ever published in book form, and she doesn't say from where the impetus came for this type of writing. Critical commentary on the condition of women published in polemical letters between 1916 and 1919 in the Maoriland Worker was 'derided' by the tutor of the Marxist study group in the Puponga mining community; it was, like her piano playing, 'a petty bourgeois trait to be despised' (PD, 67). But Devanny saw such work as informed by historical materialism - 'as interesting to me as a great novel' and as 'romance at its sublimest: the masterly clarification of all the involved and hitherto mysterious processes of social evolution!' (PD, 96). And George Winter, Secretary-General of the Communist Party of New Zealand in the early 1920s, shared her interest in anthropological writing when she met him in Wellington, and encouraged her forays into social science before he left for Sydney.

Devanny's development as a writer of fiction goes through several phases: novels of the New Woman, leavened with class and race; novels about class, leavened with sexual politics and ethnicity; novels about history, leavened with class, race and ethnicity, and gender. As in $\mathrm{DH}$ Lawrence's fiction, sexuality is a central feature of her plots. Devanny published some fourteen novels and a book of short stories; several other novels remain unpublished. She had a lucky break with an acceptance by the London publishers Duckworth early on, and the reception of her work was very good for a period. Later, changing public taste, and changes in her choices of subject matter and her sense of her audience, made her work less successful.

Devanny's earlier fiction set in New Zealand and published in the 1920s and early 1930s is mainly romances of the New Woman; her later writing in Australia shifted to socialist realism with Sugar Heaven in 1936, and then to historical fiction with Cindie in 1949. Heroines in search of sexual liberation recur in the ten novels published prior to Sugar Heaven. Many of them read what is called in Poor Swine 'the frankest kind of fiction', and this gives them sexual knowledge held up as what often characterises the 'newness' of New Women. This turning of a dispassionate eye upon the social value and 
construction of sex and sexuality is frequently commented upon as an excess of 'knowledge' in the reviewing reception of her novels in Britain and Australasia. Devanny's fictional contribution to the discussion at this time of the issues of birth control, sexual desire, marriage and the status of women is substantial and distinctive, as Nicole Moore has argued, in its refusal to concede the liberating plots of sexuality only to white, middle-class women.

Devanny had begun to write fiction when she arrived in Wellington in 1921. 'Story after story I turned out, but only a few were sold,' she recalled, later describing her early ones as 'too Harrisian' in a 1937 letter to Lily Turner (an agent with Federated Press in New York). A writing career was a difficult undertaking. 'My first book was a long time in the making. I wrote it in fits and starts. Deep down the proposition seemed chimerical and pretentious' (RR, 31). It was Jack MacDonald, an organiser for the Socialist Party of Canada, visiting in 1921-2, who encouraged her to embark upon a novel. She established 'a close intellectual bond' with him, and 'the luxury of our talks together satisfied in me, for the first time in my life, a deep need' (RR, 31ff), she wrote. The main characters of the short story 'Pals Till Hell Freezes,' Rosa and Jack, may well be based upon Devanny and MacDonald, and other of the stories collected in Old Savage feature left-wing activists.

Onerous physical labour was part of the writer's lot in the early twentieth century. When her first story was accepted in the mid-1920s, Devanny was advised to buy a typewriter, and acquired one of 'the old fashioned kind in which the roller is masked ... I had to lift the cover every two or three words to see how I was going.' She recalled, however, that 'in time, using the two middle fingers only, I became faster than the average touch typist' $(R R, 31)$. As a working class woman who rarely had any money, the habitual difficulties for an artist, and a woman artist were compounded for her. Karl and Patricia had not reached their teens in 1921 when Devanny moved to Wellington and began to write fiction. In order to practice the piano, she had earlier fastened her eldest child to the hills hoist: 'I got the notion of tying Karl up by long sliding ropes to the clothes-line and, in explaining my reasons for this, my desire for uninterrupted practice, my visitors saw the point' (PD, 67). Zora Cross, reputed according to Michael Sharkey to have installed her own children in tea chests while she worked, interviewed Devanny in Sydney in July 1930, and faithfully relayed a reassuring self-construction for the readers of the Australian Woman's Mirror:

her amazing literary story ... should be an inspiration to every woman who wants to write, for Jean Devanny did her woman's work, married and mothered and reared her family before she took up her pen. 
Eve Langley's unpublished manuscript novels ('The Old Mill', 'Last Loneliest Loveliest', 'Remote, Apart', 'Portrait of the Artist' and the unfinished 'The Saunterer'), discussed in detail by Robyn Colwill, recount the masculinism and repressive familial ideologies that prevailed even in urban leftist artistic circles in the 1920s and 1930s, in this case in Auckland, and presented considerable barriers to the emergence of the woman writer.

Shearers and miners were key among militant groupings of workers in New Zealand at this time, and two of Devanny's first three novels are set among them. Dawn Beloved is situated in the mining working class; The Butcher Shop deals with the middle-class squattocracy and the shearers who work for them; Lenore Divine is located in an urban setting of largely declassed professionals and middle-class Maori, moving in semi-bohemian circles in the New Zealand capital.

I have never been able to establish whether the novel Devanny actually wrote first was The Butcher Shop or Lenore Divine, both published in 1926, or Dawn Beloved which came out in 1928. When the first (whichever it was) was finished, she had no idea of how to get it published, but sent it off to Robert Gibbings who, happily for her, forwarded it on to the English publisher Duckworth. They did not take it at the time but told her they would consider further manuscripts. When she submitted The Butcher Shop, it was accepted, and appeared closely followed by Lenore Divine. She then revised Dawn Beloved which they published in 1928.

Devanny told the journalist, later novelist, Nelle Scanlan that, when her first novel came out, she chose the title The Butcher Shop 'because the woman is butchered in life.' She conceptualised the problem novel at this stage in this way: 'Other writers have attacked this subject, but usually they chose a women who is childless. That problem is simple. It is where there are children that the real problem arises.' Later, she would describe her initial attempt as 'terribly confused and foolish,' but she was quite isolated and had no Engels to correspond with, as did Minna Kautsky, about the difficulties of producing the tendenzroman. Duckworth would not allow her to be too didactic - or perhaps too political - and had edited out two concluding chapters. Devanny told Scanlan that 'shorn of the explanatory philosophy deleted from the end ... it does not achieve my real purpose.'

In the year that Lady Chatterley's Lover was banned, Devanny published her version of Sons and Lovers. (I have not found any mention of her having read Lawrence before she discussed him with Katherine Susannah Prichard when she passed through Perth on the boat, other than that one of her stories was published alongside his in Sun (PD, 84), but have discussed both writers' view of him in Duwell.) Dawn Beloved (1928) is a novel of a young artistic person growing up in a mining community with a drunkard miner father and a 
mother with few resources other than her piano. The Otago Daily Times read it as mainly about class, and considered it important in being 'the first attempt to depict in fiction form the home life of the West Coast miner and to analyse the reasons for his communistic tendencies.' The Melbourne Australasian found the character of Val Devoy the young miner (who has more resemblances to $\mathrm{Hal}$ than simply a name that recalls his), 'boorish, entirely self-centred, chaste and cold, and of great physical beauty ... a man who can love a woman but make her life a torment by his lack of consideration.' Val, the husband who is loved but not desired, is conveniently disposed of by a plot device, and Dawn escapes to a disinterested protector in Fuller who, she believes, 'likes me well enough to be prepared to release me from slavish housework in order to develop my ideas and find if they bear fruit' (294). She asserts of Fuller and Val:

I shall not allow either of those men to dominate my life ... I am bigger than they are.... Am I to live in ugliness all my days when roses are springing at my feet? Don't you think I have the right to gather up the sunbeams that fall around my door?

Dawn begins to 'spy tentatively between the pages of Val's sociological works' — and gets interested in working class philosophies. She tells Mrs Taylor:

'After baby is born I'll study this socialism.'

'Won't do you any good,' advised the other. 'Only make you discontented.'

Fuller who, according to Dawn's bookish brother Ralph, 'takes his opinions of [socialism] from the capitalist press' believes that socialist theory will be dangerous for Dawn because she is 'the stuff of which martyrs are made.' Such ideas as 'did the future hold nothing but tiny kitchens and brutish environments for these people?' could, he considers, be dynamite in her hands. 'Years afterwards,' we are told, Dawn argues on lecture platforms that 'passion ... must be more a cultivated attribute than a primitive instinct.' Intellectual fulfilment and expansion were to be found through the ideas in radical literature for early socialists in remote regions such as those in which Dawn - and Jean - spent their earlier years.

A group of novels set in Wellington (a comparatively larger, freer, and more anonymous environment) followed: Riven, Bushman Burke (in part) and Devil Made Saint. With Riven (1929), the focus shifts from younger New Women to the mothers to whom it is dedicated, who are also in need of liberation. To some extent, the novel can be read as a call to reject maternalist morality. The divide between the mother, Marigold, and Justine and Fay, her sister-in- 
law and daughter is to some extent bridged by the transformation of Marigold. Marigold tells Justine that it is habitual to go 'about our silly business in the calm and crouching in fear from the floods; instead of rising in our united strength and using our brains to battle with them.' Supported in the right way by older people, 'youth would be such an army of gloriously adjusted men and women as would shame to death all the creeping hobgoblins of a selfish and outgrown propriety.' In that situation, the 'greatest of all the slogans would be: "The experience of the old at the service of the young"'. Riven was reviewed, in the Wentworth Magazine of July 1930, as a book whose author

characterises, dissects and analyses with an almost surgical knife the changing views and outlook of today on what is the most important question in our racial and social life, Love and Marriage. Jean Devanny will cause some of her readers to furiously think and others to condemn, many more will applaud and agree.

Devil Made Saint was also published in 1930; 'a gloomy though powerful story of temperament and genius ... a harsh repelling story, but written with strength and insight,' was how All About Books greeted it.

Bushman Burke (1930) is part cosmopolitan, part bush. Taipo Burke, the conservative but 'good-hearted' bushman, is smitten by the exotic Flo who reads frank fiction, drinks cocktails and jazzes. This produces many conflicts after their marriage when he retreats to the bush and Flo follows. The novel revolves around a triangle that bears some similarities to that of Red Burke, Tessa and Deb in Katharine Susannah Prichard's Working Bullocks (1926). Flo, the urban New Woman, vies with Mary, the country schoolteacher, for Taipo, but it is the exotic woman that gets her man, unlike the scenario of Prichard's text. The novel embodies an interesting conflict between middleclass feminist New Woman ideology and the morality and knowledge of working-class women that Devanny in many respects validates in other novels. At one point, Taipo is unwillingly drawn into a discussion of birth control with Flo, and comments that he is surprised that she has such knowledge, admonishing her, 'The girls in my world don't'. Flo retorts, 'for goodness sake try and realise that you can't judge us by the standards of working class women.' New Zealand cultural commentators were not given to depicting their culture as crude. While Bushman Burke, when it appeared in May 1930, was dismissively summarised in All About Books as involving a 'temperamental tug of war between the "cave man" hero and the cocktail drinking heroine, which forms the gist of the novel, ending in victory for the cave man'. Isabel Maud Cluett wrote of the novel and the author: 'Bushman Burke may be said to be a riotous "saga of sex" ... although her stories all 
have a New Zealand background, and her descriptive scenes ring true enough, the dramas she unfolds have very small relation to New Zealand life, its conditions and traditions' (10).

In August 1929, when Devanny set sail for Sydney, her intention was to continue on to Britain where she seemed to have established a market for her fiction. At the end of the nineteenth century, the Tasman Sea was seen as not much more of a barrier than the state boundary between New South Wales and Victoria. There was a probability that New Zealand would federate, and the notion of Australasia was quite widely accepted. That federation did not happen has been seen as contributing to a persisting degree of insularity in New Zealand. Even at the end of the 1950s, Karl Stead considered that a 'tension exists somewhere in the mind of every New Zealander between "here" and "there"... staying and leaving', and that 'what I think the Australians call "the cultural cringe"' had lingered'. Stead invoked the 'isolation from experience' produced by 'a combination of remoteness and insignificance', compounded by 'the thinness and uniformity of its society, its dependence on Europe and America, and a certain sourness that underlies its achievements' (246-7). Historically, the lack of cultural interaction between New Zealand and Australia in the twentieth century has been pronounced, and differences between the two societies remain substantial. For Barbara Petrie, 'the geographical isolation is not as important as the cultural' and when this intersects with 'the fear of looking in the mirror of the other', it contributes to the relative paucity of cultural exchange with Australia (xxi). Rosie Scott who also moved across the Tasman to live in Sydney, fifty years after Devanny, commented that even at the end of the twentieth century it was still the case that Australians and New Zealanders did not read widely in each other's literature: 'the books are not nearly looked at enough by either side' (43). Simon During had a different take again on this in 1985 :

In those postcolonial countries which have no effective postcolonised discourse one finds a crisis of emptiness. This is true of Australia in particular. It has never been sufficiently recognised that New Zealand has a different, and more complex discursive community than Australia because the postcolonised/ postcolonising forces are balanced here as they are not there ... there is no strong postcolonised discourse by which they can mirror themselves to themselves. (371)

Scott similarly suggests that 'Maori culture has imbued Pakeha culture in a much more meaningful and obvious way' (42), in comparison to Indigenous culture in white Australia. Soon after her arrival in Sydney at the end of the 1920s, Devanny commented upon what struck her as a pervasive Australian 
racism and ethnocentrism. In her earlier novels there are many portraits of Maori characters, some are even marriage prospects for the white heroines, although it has to be said that this is not a usual occurrence in New Zealand fiction of the time. As Mary Paul points out in relation to Mander's The Story of a New Zealand River (1920), 'two of Mander's siblings married local Maori. But it is interesting that the novel does not include such a plot line' (87). White nervousness about miscegenation is foregrounded in Devanny's short story 'Mrs Salgast's Baby' (1926). Annie Salgast has her first child in the isolated Golden Ridge mining settlement and, despite her parents and her husband Bob's being believed to be of 'English' ancestry, has to agree that the baby looks like 'a Maori; a regular Maori' (31). Bob resolves to kill the only Maori man in the settlement, Tane Wetane, but then discovers from Tane that he is in fact Tane's cousin: 'Everyone knows around the pah. You think you're English, but your people only adopted you - a little baby' (39). Tane had not been able to tell him this since, he tells Bob, he had realised 'you don't like Maoris; I heard you call them bloody niggers, so I shut up' (39). A further twist occurs at the end of the story when Bob's friend, the mine manager Ashley Fletcher, goes to give Mrs Salgast the good news that 'The baby is Bob's after all', to which she replies, 'Oh, Ashes, I thought it was you' (40).

In The Butcher Shop, the immigrant, Miette, is criticised by the narrating voice as having 'English ideas about "coloured" people' and as needing 'to learn that the Maori, grand in the traditions of his race, stood equal with the average white man, and that in New Zealand, racial distinction between Hawaiki's sons and the whites was non-existent' in relation to her affair with Jimmy, son of Chief Tutaki. Dominant ideologies were of course not as progressive as this. Lenore Divine depicts middle-class Maori characters in Wellington, Ngaire Ngatoro and her brother Kowhatu, and a white heroine Lenore who, although she does not know many Maori, sleeps in the same bed as Ngaire, secretary to a Cabinet Minister. Their family, like that of Jimmy Tutaki, are aristocratic Maori, retaining aspects of their culture but highly educated within the dominant system. They mix with other middle class Maori, including the MP Noho Toki but, unlike him, vote Labour.

At home and abroad, Devanny appeared, as All About Books suggested in June 1930, 'something of an "exotic" in the field of New Zealand literature'. Reviewers, largely in Britain at this stage given the undeveloped public literary sphere in Australasia, were ambivalent about Devanny's first fiction. 'Both weak and strong, artistically and emotionally' was how the Morning Post review described Jean's earlier writing. Discussing The Butcher Shop, Jean reportedly told Nelle Scanlan that women were butchered in life 'with a fierce intensity, her luminous eyes shining, but with no trace of sordid pleasure in her discovery. People may question her talent or taste. But no one can doubt 
her sincerity.' Candour and frankness about the sexual standing of women are represented as key concerns. Devanny's later opinion of her first-published novel was not high; she saw 'its meagre merit' as 'sincerity, frankness and a certain power of phrasing.' Many of the 1926 reviews of The Butcher Shop, while ambivalent about the 'crude slabs of distasteful sex stuff,' were nonetheless favourable. The Sydney Daily Telegraph even went so far as to suggest: 'With one or two possible exceptions, this book marks the largest stride yet made by an English writer of fiction towards that absolute liberty of thought and expression possessed and exercised by the novelist of France,' and that what it might embody of French naturalism as opposed to a more restrained or even repressed English tradition was not unwelcome. The leadup to the banning in New Zealand in 1926, discussed in detail by Bill Pearson, was that the Prime Minister's secretary received a cable on 1 March urging a 'watch for new novel' that had 'alleged depiction station life New Zealand disgusting indecent communistic' (226). By 26 April, the Censorship Appeal Board (which operated very covertly) had determined that it was 'sordid, unwholesome and unclean ... it should be banned.' This decision was not announced, but the Christchurch Sun and the Press reported it in early May, and Seton Crisp in the Sydney Bulletin of 3 June 1926, commenting that it was 'crude enough' but had 'sincerity and a certain grim strength.' Jane Mander had communicated her concerns to Crisp about the novel's likely reception. While Devanny never mentions any contact with - or even any reading of - Mander or Robin Hyde, we know that they took some interest in her literary fortunes. Later, in an article in Working Woman in 1936, Hyde described The Butcher Shop as 'written with great if undisciplined power ... a work of crude ore' (5).

In another interview, 'Banned by the Censors', Devanny discussed the suppression of The Butcher Shop. 'Probably the book was banned because of its brutality, but that cannot be helped, for it is a true story of New Zealand country life.... I have lived in the country and seen for myself.' Since no grounds were officially detailed, the basis of the banning has never been entirely clear. 'It is possible the reason is that it would have been a bad advertisement for New Zealand.' She suggests, however, that its suppression might have been counter-productive: 'the censors here have given the book the best advertisement it could have' (RR, 39ff). The novel was not prohibited in Australia until after her arrival, and so achieved some readership there.

Lenore Divine's reception was less glowing. Its content was seen as unbalanced, with too much 'morbid' psychology and not enough public life: 'It would be a much better book if it gave us more New Zealand and less psychology. As it is, we have too many English authors already writing this morbid stuff to feel in urgent need of any imported goods of the same 
description, especially damaged goods', opined Edwin Pugh in the Bookman of December 1926. The opposition constructed between New Zealand and psychology is of interest here. Lenore Divine is being received as an 'exotic' Dominion novel and thus not expected to be about interiority or the subjective dilemmas of the New Woman, but about far away places and their social dilemmas: 'And the pity of it is that in the concluding chapters her psychology goes all to pieces. We don't believe in this easy swift solution of the difficulties in which she has involved her story.' This is, one might recall, the country that has a conspicuous consistent history of incarceration of its women writers in mental hospitals. That the 'solution' involves the heroine marrying a Maori may well be another significant unstated problem of the agenda here; the Aberdeen Press review of 21 October 1926 warned: 'The doctrine which she attempts to inculcate is new and bewildering; indeed its utter unconventionality would necessitate a complete revolution of the present social system. One fails, too, to see how her free-love ideals would improve matters, or how the inter-marriage of white and brown races would further the interests of civilisation.'

The book of short stories, Old Savage, appeared in 1927. Papers in Scotland seem to have taken a particular reviewing interest, perhaps because of the high proportion of Scots among New Zealand settlers. The Dundee Courier, under the heading 'A Colonial Realist,' wrote:

These New Zealand stories are not pleasant reading, for they probe the depths of passion; but they are written with a sincerity so absolute that one cannot turn away from them even when they shock and scarify sensibilities.

The Edinburgh Evening News viewed the stories as extending Devanny's move towards 'absolute liberty of thought':

Invariably the characters selected are the people of our Dominions, where life in the great lonely places is in strong contrast to the habits and morals of the civilised world; people whose reason melts before rougher instinct and passion.... Throughout, the writer disdains the theorists and presents only the truth, and, understanding the primitive moods of full-blooded men and women, she does not shrink from disclosing the harder facts of life as she knows it. (RR, 40ff).

Devanny is being taken up here in the tradition of what has been called the Empire romance novel. The term 'best-seller' came into common usage after the First World War and the Leavisite critique (as in Queenie Leavis' Fiction and the Reading Public, 1932) was a response to a growing phenomenon. 
Apart from the 'sex novel' common in the 1920s, the 'Empire romance' had many devotees along with the 'desert-love' novel. Elinor Glynn was particularly popular. But Devanny's developing fiction did not quite fit into any of the categories. In the reviews, a few key terms begin repeatedly to recur; 'sincerity' and truth to (colonial) life (of instinct and passion) are achieved, but 'the raw,' the 'brutal' and 'the unpleasant' are too much in evidence. 'She manifests little scruple,' wrote the Inquirer reviewer, 'in dealing with relations of the sexes as displayed in the wilder communities of New Zealand; but if she could get away from the subject now and again we should rate her real liberty of thought much higher than this book warrants.' The Sunday Express described her writing as 'verbose studies in desire.' The Times found most of the stories 'too richly flavoured with the ardours of sex, with love as a violent passion rather than a tender one'; when she tried to evoke tenderness (as in 'Friends of God's Acre'), it was 'over-sentimentalised.' The reviews also increasingly show a debate about the quality of Devanny's writing. Old Savage, the Aberdeen Press asserted: 'would have more literary value if the authoress's own style did not partake somewhat of the men and women of her observation - crude and raw at times.' Other reviews talked of 'a volume of exceptional quality,' and of the stories as 'masterpieces of their kind'; suggested that 'the name of Jean Devanny, already important, acquires additional significance through the fine craft and mordant character of Old Savage' (RR, 40ff).

Throughout her life Devanny, described by her daughter Pat in her Epilogue to Point of Departure as 'a woman forged in her particular circumstances, a politico beyond changing' (319), would struggle with how to prioritise politics and literature - both in terms of the time allocated to either, and in terms of how her fiction could or should engage with politics. The Butcher Shop shows an uncomfortable melding of didactic intent (an early form of what would now be called materialist feminism) and experimentation with the generic conventions of the romance. The analysis of the woman question and of racial difference that Devanny embarked upon in her early non-fictional work is embodied and further worked out through her career of fictional production. The distinctive quality of Devanny's fiction lies in the centrality of its engagement with a committed writing that included sexual politics as well as what was then conventionally called 'politics'. She said of The Butcher Shop in a 1926 interview with Nelle Scanlan: 'a good deal of the opposition to the book might be political. I cannot disassociate my writing from my Socialistic views, and the book was written with a purpose.' In Australia in the early 1930s, Devanny was mixing in circles where there was much discussion of art as a weapon and, in an essay in the early 1940s, 'The Worker's Contribution', she described her Sugar Heaven as 'the first really 
proletarian novel in Australia'. When she moved towards historical fiction, probably influenced by her friends in Australia, Eleanor Dark, Katharine Susannah Prichard, Marjorie Barnard and Flora Eldershaw, only the first of a planned three novels on the development of the sugar industry was published, and she was far less successful in this genre than they were, possibly because of her desire to make the politics of history more fully explicit.

In terms of literary influences on Devanny's developing craft, little is known of her earlier reading. She mentions as early key influences 'Conrad, Hergesheimer and, above all, Galsworthy', as well as Melville's Moby Dick which produced 'sheer palpitating wonder in reading.' The only woman writer Devanny mentions as any kind of early influence is 'the exquisite adored' Katherine Mansfield. A comment made by Mansfield in her Journal had particularly struck her: 'All that I write, all that I am, is on the border of the sea. It's a kind of playing. I want to put all my force behind it but somehow I cannot' (PD, 82), and she referred to it in 'two long lectures on the relationship between literature and society', delivered in Christchurch, claiming that the ban on The Butcher Shop had stimulated her into writing. Mansfield's fiction, largely set in the 1890s was published as Devanny was beginning to think of writing fiction; she mentions reading 'Bliss' and 'The Garden Party', and her use of the farouche outsider figure may draw upon the fondness of Mansfield, as well as Lawrence, for the traveller who offers freedom. In relation to local models, then, Devanny could find 'something different, close to me, of my own' in reading Mansfield. As well, as Gibbons suggests, the expatriate Mansfield could be for her contemporaries in New Zealand 'a symbol of the promise which could be fulfilled in the old world'. But it is also interesting to speculate whether Devanny encountered any of the New Zealand suffrage and temperance novels of the 1890s and 1900s. Titles such as Edith Searle Grossmann's In Revolt (1893) and The Heart of the Bush (1910) or Louisa Baker's A Daughter of the King (1894) and Wheat in the Ear (1898) share a marked similarity of tone with Devanny's early fiction - a high-minded feminism, a strong political impetus, a tendency towards purple prose.

The dramatists Ibsen and Shaw can be identified as some of the strongest influences upon many of the themes of Devanny's earlier fiction. Lenore Divine mentions what advanced young women of the time might be familiar with - Galsworthy's The Forsyte Saga along with Ibsen. "'Have you read Ibsen's Ghosts, Kowhatu?"' Lenore asks her future husband, "there is mention in it of a man who was worm-eaten from his birth. Poor Holly, also, is only the victim of the weakness of his progenitors. Like breeds like, dear. You are strong because you come of a strong race, and -"'. One of Devanny's first published stories, in the early 1920s in the Auckland Weekly News, was 'Wherein it Lay.' Its main protagonist, like her own father and many of her 
subsequent characters, is a victim of alcoholism, a 'vice ... which unremitting heredity had fastened on him.' His wife Eily is on the point of leaving, when she chances to read a letter from his mother condemning her for failing, through laziness, to save him from 'this curse, which passes so lightly over the heads of the mentally brutal [but] fastens with an octopus-like grip on the brightest and most beautiful of minds!' Devanny's interest in eugenics was expressed in several articles written soon after arriving in Sydney. Back in 1916, anticipating the social consequences of the carnage of World War One, Marion Piddington had proposed in a short story, 'Via Nuova: Or Science and Maternity' (written under the pseudonym of Lois), that artificial insemination might be employed to maintain the race through 'scientific or eugenic' babies. Influenced by race suicide ideology she also published articles in the early 1930s advocating sterilisation of the 'unfit'. Devanny's interest in the topic of eugenics had been developed in New Zealand and was encouraged by Piddington when she met her in Sydney. Most of the ideas of the eugenicists sit oddly with a liberatory socialism, and it is probably not to be regretted that in early 1930, Devanny could not find a publisher for 'a short work on Eugenic Reform' for 'the layman and woman', given the content of several articles she did get published on the topic in Health and Physical Culture. Piddington was Dowell O'Reilly's sister and, hence, the aunt of Eleanor Dark, and involved Devanny in her pioneering work around birth control, lecturing and setting up the first clinic in Australia in Sydney.

Devanny was a figure of some interest and controversy for her female literary contemporaries when she arrived in Sydney. Many of Hal and Jean's close friends in New Zealand, such as Paddy Webb, Bob Semple and Harry Holland had been on the far left of the New Zealand Labour Party and she had contacts around the Labour Party in Sydney. She also went to some of the gatherings organised by Dulcie Deamer, the 'Queen of Bohemia', originally from Christchurch, who had been in Sydney since the early 1920s and was on the executive of the newly-formed Fellowship of Australian Writers. Edna Ryan, then in the Communist Party, recalled that Devanny 'arrived to meet a group of a dozen, even twenty or so women all of whom would have welcomed her. She came here of course as an author, and they had a lot more prestige then than they do now.' But Devanny found that she did not really fit in at the bohemian Saturday lunches at the Café Roma.

On the other hand, Jessie Mackay, described in Macdonald et al.'s The Book of New Zealand Women as 'the first New Zealand woman poet to achieve fame at home and abroad,' and a feminist, wrote to Mary Gilmore in 1929: 'O that woman! Why should she ever have heard of me? All I've heard of her is that she goes around the country lecturing on companionate marriage, and her Butcher's Shop was banned for its morals or lack of them. 
Did she get as far as Sydney - and did she give herself out as true-blue NZ? No matter.' Other of Devanny's female Australasian contemporaries remained unimpressed with what she sought to divulge about the sexual politics of the time. Mary Fullerton agreed in a letter to Miles Franklin in 1929 that Devanny was 'no doubt sincere, but ... puts too much that is gross in her report of life.' In particular she objected to a scene involving the oral castration of lambs in The Butcher Shop.

In March 1930, Miles Franklin on a visit back to Australia noticed Devanny at the Mitchell Library, and wrote to Fullerton about how impressive and striking she looked. Fullerton was quick to reply that it might be unwise to see Devanny as aristocratic:

I'm amazed, it just shows how looks mislead sometimes for she writes like a butcher's wench and I say that not merely because she has written a book called The Butcher's Shop but because of her outlook on human character and life. Common.

Compared to 'that dear little GB Lancaster' Devanny was consistently excessive, in Fullerton's view, and 'in straining to be red blooded masculine, she only manages to be raw meat' (RR, 60ff). Franklin nonetheless remained a supporter of Devanny. She would write to Alice Henry in 1935:

Jean Devanny is a New Zealander, a red revolutionist and ranter, but I like her very much. I read her Butcher's Shop. She tries to ape the overseas advanced stuff which gives her work a strained effect - too yeasty. Shows lack of education and lack of natural depth that wd not be apparent if she wd be quieter.

Despite this, a close friendship, conducted through letters and a few visits, developed between Franklin and Devanny through the 1940s and, when the latter was working on her Autobiography, Franklin encouraged and advised her, as the correspondence published in Ferrier ed. As Good As a Yarn with You shows.

Soon after arriving in Sydney, the family being short of money, Devany hit upon the idea of going out bush to work as a domestic. She only lasted there for a few months, but was able to describe The Killing of Rosamond Lovatt as drawing upon Australian experiences of working in the bush, although this may originally have been drafted as a New Zealand novel. In her first attempt to establish herself with an Australian publisher, she suggested in 1930 to Angus and Robertson that it might be marketed as `first Australian novel of Jean Devanny, author of The Butcher Shop: Love and Mystery on a Western sheep station.' The Reader's Report, however, suggested that Jean's publicity 
proposals would produce 'caustic criticism' for 'both publishers and author' since the novel was 'no more Australian than Devanny is.' While the novel was 'melodramatic to a degree and reeking with sex - two selling points nowadays', the report's author was definite that 'One cannot imagine a more un-Australian lot of characters' (RR, 65ff). Read earlier as un-New Zealand, Devanny now found herself un-Australian as well. Worse, her empire romances were becoming less attractive to Duckworth who 'on account of an anti-religious bias pervading its main theme' considered Out of Such Fires, another novel of the bush, and the first set in Australia, 'unsuitable for publication in England.' It did, however, come out in New York in 1934.

In March 1932, Poor Swine, which had been completed on the boat to Europe, was threatened with being banned. In the event it was not. Devanny may well have been unaware that the opinion of Customs that it focussed upon 'the life of a woman who has very little moral fibre' and was not 'a book one would like to have in the house', nearly resulted in proceedings against it. The reception of Devanny's work in mainstream reviewing channels was also beginning to become more negative. Poor Swine comes over as a rather more cynical reworking of a similar plotline to that of Dawn Beloved; it was not appreciated by the reviewer of All About Books 14 June 1932, who complained that Devanny was

attempting to hold her public by clever 'modern' portrayals of dissolute characters. It is the same old creed - environment, heredity, circumstance, personal charm and attributes are all made the excuse for the main character to trample selfishly and dishonourably over every despised convention and ethics ... by definitely appealing for the reader's sympathy, the author hoists a banner of conscienceless 'freedom' that may be waved whenever an excusing circumstance may be found (RR, 102ff).

While in Wellington, Devanny had been closely involved with far left circles but had not joined either of the two Communist Party groupings that existed there in the mid-1920s. The official one, led by the Griffin brothers and Gordon Kilpatrick, of about 10-16 members, was 'very puritanical' and, as Bert Roth, the Auckland labour historian, personally told me, condemned the other on the grounds that they 'went to dances, drank, and slept with each other.' Jean and Hal were associated with the wilder group. Later, trying to remember this part of the past for her Autobiography, Jean recalled it as 'a montage of street corner meetings, hall meetings, social gatherings, of street collections and work on behalf of the unemployed.'

It was not until Devanny had been in Sydney for a while that she joined the Communist Party - against the advice of Marion Piddington who told her 
'You are not tough enough for them', and who even offered Jean her cottage in the Blue Mountains as a writer's retreat. But despite Devanny's commitment to the importance of literature - asserted for example in her 1930 article that compared 'true literary thought' to 'pillars of fire guarding and guiding the line of humanity's progress' - she didn't opt, as did Eleanor Dark, for a comparatively quiet life in the country. Despite the resultant lack of time for writing, she hurled herself into the struggles of the Depression and was much in demand as an agitational public speaker. 'I was assigned to numberless tasks, but most of all to platform and "soapbox" work', she recalled (PD, 130).

Devanny nevertheless completed two more novels at this time, The Ghost Wife and The Virtuous Courtesan. 'Though I had ceased to regard fiction writing as of any importance, there was still the necessity to earn some money,' she commented. The Virtuous Courtesan is a significant novel, despite being produced when time was at a premium, for its picture of Sydney bohemia and in being one of the very first Australasian novels to draw lesbian and homosexual characters. Published in the United States in 1935, it was speedily banned in Australia.

In the mid-1930s, Devanny made a turn to the 'industrial novel' and to 'reportage.' She had been spending time in Mt Isa and north Queensland, after travelling there initially on speaking tours for the Movement Against War and Fascism, doing organisational political work in relation to the impending Spanish Civil War. North Queensland was at this period known as the Red North, with large numbers of socialists among the workers in the sugar and other industries. Many were European migrants, a number of whom, as Nettie Palmer would document, went to Spain. Sugar Heaven was the first of Devanny's sugar industry novels, and was based upon the major canecutters' strikes over the plague-like Weil's Disease in the mid-1930s. Devanny's next sugar novel was Paradise Flow (1938) which, like Sugar Heaven, is interested in ethnicity, and in the NESB Migrant population as an exploited group subject to discrimination. A Lawrencean vitalism is found in the figure of Muranivich in Paradise Flow, whose complexity is prefigured in the assertion in Sugar Heaven that Slavs, like Chinese, give an impression of coming from a more mature cultural background than Anglo-Australians. Again, before much more recent assessments of figures such as Francis Adams by writers including Meg Tasker, Devanny is picking up on much more complicated understandings. Amelia Batistich's fiction of the 1940s about Dalmatian gum diggers in New Zealand would engage with similar communities.

Devanny planned a historical trilogy of the development of the sugar industry but only two volumes were completed and only one ever published, Cindie in 1949. This deals largely with the time of indentured labour of South 
Sea Islanders, from the 1860s when Queensland was regarded potentially as a second Louisiana following the end of slavery in the United States, until, with Federation at the turn of the century, most 'Kanakas' were forcibly repatriated. Cindie is also interested in the position of the Indigenous people, but most of the writing Devanny did in this regard was non-fiction, in travel books and articles. Despite her writing back to Working Bullocks, as noted above; for whatever reasons, Prichard's Coonardoo and goldfields novels did not inspire her to a similar endeavour of making Aboriginal characters central and prominent in her work. The only substantial Australian Indigenous characters she creates are the Torres Strait Islanders in her novel The Pearlers, which remains unpublished.

Devanny's earlier great success in publishing with Duckworth was not maintained. Through the 1950s until her death in Townsville in 1962 she managed to publish almost nothing further, for a complex range of reasons including a Cold War climate very oppressive for socialist women. Also of relevance here was her lack of favour in the Australasian Book Society, controlled by the Communist Party.

It is interesting to consider how Devanny's literary career might have been different had she remained in New Zealand: whether she would have had a substantial impact upon the development of New Zealand political and literary life, or whether she would have been stifled in various ways. She flirted with the idea of returning there in the 1950s, but never did. Robin Hyde suggested, in her Foreword to The Godwits Fly (published not long before she died in London in her early thirties) that the birds symbolised 'our youth, our best, our intelligent, our brave and beautiful [who] must make the long migration, under a compulsion they can hardly understand, or else be dissatisfied all their lives long.' Devanny did not expect her migration to take her merely across the Tasman but, apart from one visit to Europe on political business, that is how it turned out. Her migration away from a culture that was repressive and restrictive for the person and writer she was and aspired to be did not take her as far as she might have wished. But her analyses of oppression and freedom, as experienced in her early life in New Zealand, continued to permeate her fiction and still offer much to be examined and evaluated.

\section{LINKS}

Australian Dictionary of Biography

Dictionary of New Zealand Biography

James Cook University Archives

New Zealand Electronic Text Centre (NZETC)

New Zealand Literature File 


\section{BIBLIOGRAPHY}

\section{BOOKS}

\section{Fiction, Travel and Autobiography}

The Butcher Shop. London: Duckworth, 1926; New York: Macaulay, 1926; Berlin: Th. Knau Nachf, 1928. Also published as Die Herrin. Auckland: Auckland University

Press, 1981; intro. H. Roberts, with a note by B. Pearson on its banning.

Lenore Divine. London: Duckworth, 1926.

'Mrs Salgast's Baby.' New Coterie, 4 (1926): 28-40.

Old Savage and Other Stories. London: Duckworth, 1927.

Dawn Beloved. New York: Macaulay, 1928; London: Duckworth, 1929.

Riven. London: Duckworth, 1929; 1934; New York: Macaulay, 1930, as Unchastened Youth.

Bushman Burke. London: Duckworth, 1930; New York: Macaulay, 1930 as Taipo.

Devil Made Saint. London: Duckworth, 1930.

Poor Swine. London: Duckworth, 1932; New York: Macaulay, 1932, as All for Love.

Out of Such Fires. New York: Macaulay, 1934.

The Ghost Wife. London: Duckworth, 1935.

The Virtuous Courtesan. New York: Macaulay, 1935.

Sugar Heaven. Sydney: Modern Publishers, 1936; Sydney: Frank Johnson, 1942; abridged as Sakharnyirai. Moscow: Izd-vo Khudozh Lit-ry, 1963; Melbourne:

Redback Press, 1982, intro. C. Ferrier; new scholarly edition, ed. and intro. N.

Moore, Melbourne: Vulgar Press, 2002.

Paradise Flow. London: Duckworth, 1938.

The Killing of Jacqueline Love. Sydney: Frank Johnson, 1942.

By Tropic Sea and Jungle. Sydney: Angus and Robertson, 1944.

Bird of Paradise. Sydney: Frank Johnson, 1945.

Roll Back the Night. London: Robert Hale, 1945.

Cindie. London: Robert Hale, 1949. London: Virago, 1986. Intro. C. Ferrier.

Travels in North Queensland. London: Jarrolds, 1951.

Point of Departure: The Autobiography of Jean Devanny, intro. C. Ferrier; epilogue P. Hurd. St Lucia: University of Queensland Press, 1986.

\section{Other}

'The Worker's Contribution to Australian Literature.' Australian Broadcasting Commission/Fellowship of Australian Writers. Australian Writers Speak: A Series of Talks Arranged by the Fellowship of Australian Writers for the Australian Broadcasting Commission. Sydney: Angus and Robertson, 1942.

'The Literary Moral Standard.' Stead's Review, 1 July 1930: 12.

Paradise Flow: The Play, intro. C. Ferrier, preface D. Menghetti. Brisbane: Hecate Press, 1985. 


\section{REFERENCES}

Baker, Candida. Yacker 2: Australian Writers Talk About Their Work. Sydney: Picador, 1987.

'Banned By the Censors: The Butcher's Shop. Written By New Zealand Woman.' NZ Times, 4 June 1926.

Colwill, Robyn. "'Corridors of Memory, Passages of the Past": The Retrieval of Eve Langley'. PhD thesis, University of Queensland, 2001.

Cross, Zora ('Bernice May'). 'Jean Devanny.' Australian Woman's Mirror, 29 July 1930: 10.

Cluett, Isabel Maud. 'Exodus of New Zealand Writers.' All About Books, 17 June 1930: 164.

Dever, Maryanne ed. Wallflowers and Witches: Women and Culture in Australia, 1910-1945. St Lucia: University of Queensland Press, 1994.

During, Simon. 'Postmodernism or Postcolonialism?' Landfall, 155, 39:3 (September 1985): 366-380.

Duwell, Martin and Irmtraud Petersson, eds. And What Books Do You Read? St Lucia: University of Queensland Press, 1996.

Ferrier, Carole, ed. As Good as a Yarn with You: Letters Between Miles Franklin, Katharine Susannah Prichard, Jean Devanny, Marjorie Barnard, Flora Eldershaw and Eleanor Dark. Cambridge: Cambridge University Press, 1992.

Ferrier, Carole. Jean Devanny: Romantic Revolutionary. Melbourne: Melbourne University Press, 1999.

Franklin, Miles. Laughter, Not for a Cage: Notes on Australian Writing, With Biographical Emphasis on the Struggles, Function and Achievements of the Novel in Three Half-Centuries. Sydney: Angus and Robertson, 1956.

Gibbons, P. J. 'The Climate of Opinion.' The Oxford History of New Zealand. Eds. W. H. Oliver et al. Wellington: Oxford University Press, 1981, pp. 302-330.

Guiffré, Giulia. A Writing Life: Interviews with Australian Women Writers. Sydney: Allen and Unwin, 1990.

Hulme, Keri. In Our Own Country: Leading New Zealand Writers Talk About Writing and Their Lives. Ed. Sue Kedgley. Harmondsworth: Penguin, 1989.

Hyde, Robin. 'The New Zealand Woman in Letters.' Working Woman (Wellington), 3:6 (April 1936).

Macdonald, Charlotte, et al., eds. The Book of New Zealand Women: Ko Kui Ma Te Kaupapa. Wellington: Bridget Williams Books, 1991.

'Bernice May' [Zora Cross]. Australian Woman's Mirror, 29 July 1930: 10.

Melman, Billie. Women and the Popular Imagination in the Twenties: Flappers and Nymphs. London: Macmillan, 1988.

Modjeska, Drusilla. Exiles at Home: Australian Women Writers 1925-1945. Sydney: Angus and Robertson, 1981.

Moore, Nicole. 'Interrupting Maternal Citizenship: Birth Control in Mid-wave Women's Writing.' Australian Feminist Studies, 17:38 (2002): 151-165.

Nola, Nina. 'Migrant Women's Writing in New Zealand: Amelia Batistich's Three Dimensional World.' Hecate, 20:2 (1994): 140-159.

Paul, Mary. Her Side of the Story: Readings of Mander, Mansfield and Hyde. Dunedin: University of Otago Press, 1999.

Petrie, Barbara, ed. Kiwi and Emu: An Anthology of Contemporary Poetry by Australian and New Zealand Women. Springwood, NSW: Butterfly Books, 1989. 
Ryan, Edna. Interview, Carole Ferrier. Sydney, 16 January 1984. Tape: CF.

Samuels, Selena, ed. Dictionary of Literary Biography: Australian Writers 1915-1950. Vol 260. Bruccoli Clark Layman/Thomson/Gale, 2002.

Scanlan, Nelle M. 'Banned by the Censors.' New Zealand Free Lance. 26 May 1926.

Scott, Rosie. Interview with Laurel Bergmann. Hecate, 18:2 (1992): 33-45.

Sharkey, Michael. 'Zora Cross's Entry into Australian Literature.' Hecate,16, 1/2 (1990): 65-89.

Stead, C. K. In the Glass Case: Essays on New Zealand Literature. Auckland: Oxford University Press, 1981.

Tasker, Meg. Struggle and Storm: The Life and Death of Francis Adams. Carlton, Vic: Melbourne University Press, 2001. 